\title{
Ülseratif kolitli hastalarda paraoksanaz 1 ve arilesteraz seviyeleri ve bu parametrelerin hastalık aktivitesi ile ilişkileri
}

\author{
Paraoxonase 1 and arylesterase levels in patients with ulcerative colitis and their relationship with \\ disease activity
}

\author{
Volkan GÖKBULUT'1 , Hakan DURSUN², Mustafa KAPLAN³, Erkin ÖZTAŞ4 \\ Türkiye Yüksek Intisas Eğitim ve Araştırma Hastanesi, ' 'Gastroenteroloji Kliniği, Ankara \\ Atatürk Üniversitesi Tıp Fakültesi, ${ }^{2}$ Gastroenteroloji Bilim Dalı, Erzurum \\ Ahi Evran Üniversitesi Tıp Fakültesi Hastanesi, ${ }^{3}$ Gastroenteroloji Kliniği, Kırşehir \\ Osmangazi Üniversitesi Tıp Fakültesi, ${ }^{4}$ Gastroenteroloji Bilim Dalı, Eskişehir
}

\begin{abstract}
Giriş ve Amaç: Bu çalışmada ülseratif kolitli hastalarda serum paraoksonaz 1 ve arilesteraz düzeyleri ve bu parametrelerin hastalık aktivitesi ile ilişkileri araştıııldı. Gereç ve Yöntem: Çalışmaya 38 aktif dönemde ülseratif kolit hastası ve 38 sağlıklı kontrol grubu hastası dahil edildi. Çaıı̧̧ma grubu hastalarından hem aktif dönemde hem de remisyon sağlanınca paraoksonaz 1 ve arilesteraz enzim aktiviteleri çalışıldı. Paraoksonaz 1 ve arilesteraz enzim aktiviteleri aktif dönem, remisyon dönemi ve kontrol grubu arasında kıyaslandı. Bulgular: Çalışma grubu hastalarının

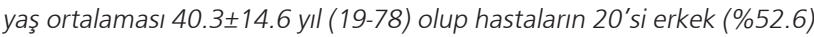
ve 18 'i kadın (\%47.4) idi. Kontrol grubu hastalarının demografik özellikleri çalışma grubuna benzerdi. Aktif dönemdeki ülseratif kolit hastalarııı ortalama serum paraoksonaz 1 değeri $65.8 \pm 15.0 \mathrm{U} / \mathrm{L}$, ortalama serum arilesteraz değeri ise $151.0 \pm 236.6 \mathrm{U} / \mathrm{mL}$ olarak tespit edildi. Remisyon dönemindeki hastalarda ortalama serum paraoksonaz 1 değeri $82.4 \pm 58.4 \mathrm{U} / \mathrm{L}$, ortalama serum arilesteraz değeri ise $94.1 \pm 134.6 \mathrm{U} /$ $\mathrm{mL}$ olarak tespit edildi. Kontrol grubundaki hastalarda ortalama serum

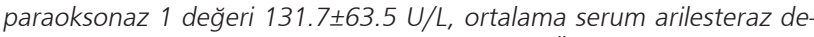
ğeri ise $287.3 \pm 295.6 \mathrm{U} / \mathrm{mL}$ olarak tespit edildi. Ülseratif kolitli hastalarda ortalama paraoksonaz 1 ve arilesteraz düzeyleri aktif ve remisyon dönemi arasında istatistiksel olarak anlamlı fark göstermedi ( $p>0.05)$. Aktif ve remisyon dönemindeki ülseratif kolitli hastalarda ortalama paraoksonaz 1 ve arilesteraz değerleri kontrol grubundaki sağ lıklı bireylere göre istatistiksel olarak anlamlı şekilde düşük bulundu ( $p<0.05)$. Sonuç: Ülseratif kolitli hastalarda paraoksonaz 1 ve arilesteraz aktivitelerinin kontrol grubuna göre istatiksel olarak anlamlı şekilde azaldığı ancak hastalık aktivitesi ile paraoksonaz 1 ve arilesteraz aktiviteleri arasında ilişki bulunmadığı gösterilmiştir.
\end{abstract}

Anahtar kelimeler: Paraoksonaz 1, inflamatuvar barsak hastalığı, ülseratif kolit

\section{GíRiş}

Ülseratif kolit (ÜK) primer olarak kolonu tutan, mukoza ve submukozaya sınırlı, idiyopatik kronik bir hastalıktır (1). İnflamatuvar barsak hastalığı (IBH) patogenezinde en çok genetik, immünolojik, mikrobiyolojik ve çevresel fak-

Iletişim: Mustafa KAPLAN

Ahi Evran Üniversitesi Tıp Fakültesi Hastanesi, Gastroenteroloji Kliniği, Kırşehir Faks: +903863124120

E-mail: mustafakaplandr@yahoo.com
Background and Aims: In this study, we studied serum paraoxanase 1 and arylesterase levels in patients with ulcerative colitis and their relationship with disease activity. Material and Methods: Thirty-eight patients with active ulcerative colitis and 38 healthy controls were included in this study. Paraoxanase 1 and arylesterase enzyme activities in both active and remission phases were studied. Paraoxanase 1 and arylesterase enzyme activities in the active disease phase, the remission phase, and the control group were compared. Results: The mean patient age in the study group was $40.3 \pm 14.6$ years (19-78); 20 patients were male (52.6\%) and 18 were female (47.4\%). The demographic characteristics of the patients in the control group were similar to those of the study group. The mean serum paraoxanase 1 level was $65.8 \pm 15.0 \mathrm{U} / \mathrm{L}$, and the mean serum arylesterase level was $151.0 \pm 236.6 \mathrm{U} / \mathrm{mL}$ in patients in the active phase. The mean serum paraoxanase 1 level was $82.4 \pm 58.4 \mathrm{U} / \mathrm{L}$, and the mean serum arylesterase level was $94.1 \pm 134.6 \mathrm{U} / \mathrm{mL}$ in patients in the remission phase. The mean serum paraoxanase 1 level was $131.7 \pm 63.5 \mathrm{U} / \mathrm{L}$, and the mean serum arylesterase level was $287.3 \pm 295.6 \mathrm{U} / \mathrm{mL}$ in the control group. There was no statistically significant difference in mean paraoxanase 1 and arylesterase levels between patients in the active and remission phases $(p>0.05)$. The mean levels of paraoxanase 1 and arylesterase in patients in the active and remission phases were significantly lower than those in healthy controls $(p<0.05)$. Conclusion: In patients with ulcerative colitis, paraoxanase 1 and arylesterase enzyme activities were found to be significantly lower than those in the control group, but there was no relationship between disease activity and paraoxanase 1 and arylesterase enzyme activities.

Key words: Paraoxanase 1, inflammatory bowel disease, ulcerative colitis

törler suçlanmaktadır (2-4). ÜK 100 yıldan daha uzun bir süredir bilinen bir inflamatuvar barsak hastalı̆ı̆ olmasına rağmen etiyolojisi ve patogenezi hala tam olarak aydınlatılamamıştır.

Gökbulut V, Dursun H, Kaplan $M$, et al. Paraoxonase 1 and arylesterase levels in patients with ulcerative colitis and their relationship with disease activity. The Turkish Journal of Academic Gastroenterology 2019;18:33-37. DOI: 10.17941/ agd.543505

Geliş Tarihi: 30.06 .2018 • Kabul Tarihi: 27.10.2018 
Insanda 7. kromozomun q21-22 bölgesinde lokalize paraoksonaz (PON) multigen ailesi, PON1, PON2 ve PON3 diye adlandırılan üç üyeden oluşmaktadır (5). Paraoksonaz enzimi karaciğerde sentezlenen bir ester hidrolazdır (6). PON1'in düşük yoğunluklu lipoprotein (LDL) kolesterolün oksidatif modifikasyonuna karşı koruyucu bir rol oynayarak lipit peroksidasyonunu engellediği, antioksidan ve anti-inflamatuvar özellik gösterdiği belirtilmektedir (79). Paraoksonaz ve arilesteraz (ARE) iki ayrı enzim olarak adlandırılsa da yapılan araştırmalarda insan serumunda tek gen ürünü olan enzimin hem arilesteraz hem de paraoksonaz aktivitesine sahip olduğu gösterilmiştir (10).

Plazma PON1 ve ARE aktiviteleri patolojik şartlarda özellikle malign hastalıklarda ve kronik sistemik hastalıklarda azalmış olarak bulunmuştur (11-13). Bu çalışmalarda artmış oksidasyon ve inflamasyonun etkisi ile PON1 ve ARE değerlerinin azaldığı belirtilmiştir. ÜK'nin etiyolojisinde de daha önceki çalışmalarda inflamasyon ve oksidasyonun önemli rolü gösterilmesine rağmen ÜK'da PON1 ve ARE düzeyleri ve bu parametrelerin hastalık aktivitesi ile ilişkisini kıyaslayan literatürde az sayıda çalışma bulunmamaktadır.

Biz bu çalışmada ülseratif kolitli hastalarda serum PON1 ve ARE düzeylerini ve bu parametrelerin hastalık aktivitesi ile ilişkisini araştırdık.

\section{GEREÇ ve YÖNTEM}

Çalışmamıza Atatürk Üniversitesi Tıp Fakültesi Hastanesi Gastroenteroloji polikliniğine kanlı ishal şikayeti ile başvuran ve yeni tanı konulmuş veya remisyonda iken nüks hastalık tanısılla hospitalize edilen 38 aktif dönemde ÜK hastası ve 38 sağıklı kontrol grubu hastası dahil edildi. Hastalık aktivite değerlendirmesi Truelove-Witts skorlamasına göre yapıldı (14). Bu skora göre şiddetli hastalığı olanlar aktif ÜK olarak alındı.

Çalışmaya böbrek yetmezliği, kronik karaciğer hastalığı, kronik kalp hastalığı, İBH dışında sistemik inflamatuvar veya sistemik enfeksiyöz hastalığı olanlar ve herhangi bir malignite tanısı olan hastalar dahil edilmedi. Aktif dönemdeki tüm hastalarımız yatırılarak tedavi edildi. Hastalara $1 \mathrm{mg} / \mathrm{kg}$ dozunda metilprednisolon ve remisyon sağlanamadığı durumlarda anti- tümör nekrozis faktör (TNF) tedavi verilerek remisyon sağlandı. Hastalar remisyona girdikten üçer aylık sürelerle kontrole çağrıldı. Kontrole gelen hastaların remisyonda oldukları Truelove-Witts kriterleri ile teyit edildi.

ÜK'li hastalarda aktif ve remisyon döneminde PON1 ve ARE düzeyleri ölçüldü. Sağlıklı kontrol grubunun da PON1 ve ARE düzeyleri ilk başvuru anında ölçüldü. Çalışmada aktif dönemdeki hastaların PON1 ve ARE düzeyleri re- misyon dönemiyle karşılaştıııldı. Aynı zamanda hem aktif hem remisyon dönemindeki hastaların PON1 ve ARE düzeyleri sağ|ıkı kontrol grubuyla karşılaştıııldı.

ÜK hastalarından tedaviye başlamadan önceki aktif dönemlerinde ve tedaviyle remisyon dönemine girdikten sonraki zamanda $10 \mathrm{ml}$ venöz kan alındı. Aynı şekilde sağlıklı gönüllülerden de kan alındı. PON1 ve ARE düzeyleri için alınmış olan venöz kanlar en fazla 30 dakika oda sıcaklığında dik pozisyonda bekletildikten sonra, biyokimya laboratuvarında 4000 rpm'de 10 dakika soğutmalı santrifüj edildi. Ayrilan serum iki eşit parçaya bölünerek -80 derecede depolanıp saklandı. Çalışmanın yapılacağı gün tüm numunelerin $+4{ }^{\circ} \mathrm{C}^{\prime}$ de 12 saat bekletilerek çözünmeleri sağlandı ve biyokimya laboratuvarında çalışıldı.

PON1 enzim aktivitesi ölçümünde substrat olarak paraokson, ARE ölçümünde ise substrat olarak fenil asetat kullanıldı. Kullanılan bütün kimyasallar analitik saflıkta olup Merck ve Sigma'dan sağlandı. Serum havuzunda paraoksonaz aktivite ölçümlerinde farklı konsantrasyonlarda $\mathrm{CaCl} 2$ ve yine farklı konsantrasyonlarda paraokson (O,O-diethyl-O-p-nitrophenyphosphate; Sigma Co, London, UK) ihtiva eden glisin ve Tris-HCL tamponları kullanılarak; farklı pH ve sıcaklıklarda $\left(37^{\circ} \mathrm{C}\right.$ ve $25^{\circ} \mathrm{C}^{\prime}$ de) ölçümler yapılarak bazal paraoksonaz aktiviteleri incelendi. Aynı solüsyonlara $0.5 \mathrm{~mol} / \mathrm{L}$ ve $1 \mathrm{~mol} / \mathrm{L} \mathrm{NaCl}$ ilaveleri yapılarak da NaCl-stimüle paraoksonaz aktiviteleri tespit edildi. Arilesteraz aktivitesi ölçümleri ise Tris- $\mathrm{HCl}$ ve glisin tamponlarına substrat olarak paraokson yerine son konsantrasyonu $1 \mathrm{mmol} / \mathrm{L}$ ve $2 \mathrm{mmol} / \mathrm{L}$ olacak şekilde fenilasetat ilave edildi. PON1'in enzimatik hidrolizi sonucu oluşan 4-nitro-fenol ile ARE'nin enzimatik hidrolizi sonucu oluşan fenol spektrofotometrik olarak ölçüldü. PON1 aktivitesi 412 nm'de, ARE enzim aktivitesi 270 nm'de ölçüldü.

Veriler sayı, yüzde ortalama ve standart sapma olarak verildi. Verilerin analizinde SPSS 18 bilgisayar istatistik programı kullanıldı. Nümerik veriler parametrik şartlarda kontrol grubu ile T testi ile, nonparametrik şartlarda Mann-Whitney U Test ile analiz edildi. $p<0.05$ olması durumunda gruplar arası fark anlamlı kabul edildi.

\section{BULGULAR}

Çalışma grubu hastalarının yaş ortalaması $40.3 \pm 14.6$ yıl (19-78) olup hastaların 20'si erkek (\%52.6) ve 18'i kadın (\%47.4) idi. Kontrol grubu hastalarının ise yaş ortalaması $40.5 \pm 9.9$ (18-60) olup hastaların 21 'i erkek (\%55.2) ve 17 'si kadın (\%44.8) idi. Çalışma ve kontrol grubu hastalarının demografik özellikleri benzerdi. Çalışma grubu hastalarının $18^{\prime}$ inde pankolit, $15^{\prime}$ inde sol tip kolit ve $5^{\prime}$ inde ise ülseratif proktit mevcuttu. Hastaların demografik özellikleri Tablo 1'de özetlenmiştir. 
Tablo 1. Demografik özellikler

\begin{tabular}{lccc} 
& Çalışma Grubu & Kontrol Grubu & p \\
\hline Yaş & $40.3 \pm 14.6$ yl $(19-78)$ & $40.5 \pm 9.9(18-60)$ & 0.78 \\
\hline Cinsiyet: E/K & $20(\% 52.6) / 18(\% 47.4)$ & $21(\% 55.2) / 17(\% 44.8)$ & 0.69 \\
\hline Hastalık tutulumu & & & \\
$\quad$ Pankolit & $18(\% 47)$ & - & \\
Sol tip & $15(\% 39)$ & & \\
Ülseratif proktit & $5(\% 17)$ & & \\
\hline
\end{tabular}

Tablo 2. Hastalık dönemlerine göre PON1 ve ARE değerleri ve gruplar arasında kıyaslama

\begin{tabular}{|c|c|c|c|c|}
\hline & PON1 & & ARE & \\
\hline $\begin{array}{l}\text { Aktif dönem } \\
\text { Remisyon dönemi }\end{array}$ & $\begin{array}{l}65.8 \pm 15.0 \mathrm{U} / \mathrm{L} \\
82.4 \pm 58.4 \mathrm{U} / \mathrm{L}\end{array}$ & $p>0.05$ & $\begin{array}{l}151.0 \pm 236.6 \mathrm{U} / \mathrm{mL} \\
94.1 \pm 134.6 \mathrm{U} / \mathrm{mL}\end{array}$ & $p>0.05$ \\
\hline $\begin{array}{l}\text { Aktif dönem } \\
\text { Kontrol }\end{array}$ & $\begin{array}{c}65.8 \pm 15.0 \mathrm{U} / \mathrm{L} \\
131.7 \pm 63.5 \mathrm{U} / \mathrm{L}\end{array}$ & $p<0.005$ & $\begin{array}{l}151.0 \pm 236.6 \mathrm{U} / \mathrm{mL} \\
287.3 \pm 295.6 \mathrm{U} / \mathrm{mL}\end{array}$ & $p<0.05$ \\
\hline $\begin{array}{l}\text { Remisyon dönemi } \\
\text { Kontrol }\end{array}$ & $\begin{array}{c}82.4 \pm 58.4 \mathrm{U} / \mathrm{L} \\
131.7 \pm 63.5 \mathrm{U} / \mathrm{L}\end{array}$ & $p<0.005$ & $\begin{array}{c}94.1 \pm 134.6 \mathrm{U} / \mathrm{mL} \\
287.3 \pm 295.6 \mathrm{U} / \mathrm{mL}\end{array}$ & $p<0.005$ \\
\hline
\end{tabular}

PON1: Paraoksanaz 1, ARE: Arilesteraz

Hastalık dönemlerine göre PON1 ve ARE değerleri ve gruplar arasında kıyaslama Tablo 2'de özetlenmiştir. Aktif dönemdeki ÜK hastalarının ortalama serum PON1 değeri $65.8 \pm 15.0 \mathrm{U} / \mathrm{L}$, ortalama serum ARE değeri ise $151.0 \pm 236.6 \mathrm{U} / \mathrm{mL}$ olarak tespit edildi. Remisyon dönemindeki hastalarda ortalama serum PON1 değeri 82.4 $\pm 58.4 \mathrm{U} / \mathrm{L}$, ortalama serum ARE değeri ise $94.1 \pm 134.6 \mathrm{U} / \mathrm{mL}$ olarak tespit edildi. Kontrol grubunda-

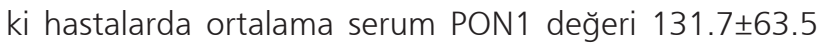
$\mathrm{U} / \mathrm{L}$, ortalama serum ARE değeri ise $287.3 \pm 295.6 \mathrm{U} / \mathrm{mL}$ olarak tespit edildi.

ÜK'lı hastaların PON1 ve ARE düzeyleri kıyaslandığında aktivasyon ve remisyon dönemleri arasında istatistiksel olarak anlamlı fark bulunmadı ( $p>0.05)$. Aktivasyon dönemindeki ÜK'lı hastalarda ortalama PON1 ve ARE değerleri kontrol grubundaki sağlıklı bireylere göre istatistiksel olarak anlamlı şekilde düşük bulundu (PON1 p<0.05, ARE $p<0.5)$. Yine remisyon dönemindeki ÜK'lı hastalarda ortalama PON1 ve ARE değerleri kontrol grubundaki sağılıklı bireylere göre istatistiksel olarak anlamlı şekilde düşük bulundu $(p<0.05)$.

\section{TARTIŞMA}

Bu çalışmada PON1 ve ARE seviyelerinin aktif ve remisyon dönemindeki ÜK hastalarında kontrol grubu hastalarına göre azaldığı ve bu parametrelerin hastalık aktivitesi ile ilişkili olmadığı gösterilmiştir. Hem aktif dönemde hem de remisyon döneminde kontrol grubuna göre daha düşük PON1 ve ARE değerlerinin bulunması hastalı̆ı̆ etyopatogenizinde serumda bu moleküllerin seviyelerinin azalmasının rolü olabileceğini düşündürmektedir.

Daha önceki çalışmalarda malignite, travma ve romatoid artrit gibi artmış oksidatif stres altındaki hastalıklarda azalmış PON1 ve ARE aktiviteleri saptanmıştır (15-17). Akçay ve ark. yapmış oldukları çalışmada mide ve pankreas kanserli hastalarda azalmış serum PON1 aktivitesi saptamışlartır $(18,19)$. Yine Elkıran ve ark. yeni tanı akciğer kanserli hastalar üzerinde yaptıkları çalışmada PON1 ve ARE aktivitesini anlamlı oranda azalmış bulmuşlardır (20). Ancak literatürde ÜK ile bu parametreler arasındaki ilişkiyi ve bu parametrelerin hastalık aktivitesi ve etyopatogenezdeki rolünü araştıran çalışma sayısı kısıtıdır.

ÜK'nın etyopatogenezi hala tam olarak anlaşılamamıştır. Serbest radikalleri içeren oksidan moleküllerin IBH'nın patofizyolojisinde rol oynadığı düşünülmektedir (21). Kolon göreceli olarak mukozasındaki düşük orandaki antioksidanlara bağlı olarak oksidatif hasara zaten duyarlıdır. Ayrıca ÜK'da azalmış antioksidan defans mekanizmaları aşırı inflamasyonun gelişimine neden olabilir $(22,23)$. Antioksidan defans mekanizmasının azalmasında ise PON1 gibi antioksidan moleküllerinde azalmanın rolü olduğu düşünülmektedir. PON1'in lipoproteinler üzerinde serbest radikallerin yol açtığı lipit peroksidasyonuna karşı antioksidan etki gösterdiği gözlenmiştir (24). Bizim 
çalışmamızda da ÜK hastalarında serumda PON1 seviyesinin kontrol grubu hastalarına göre istatistiksel olarak anlamlı şekilde düşük bulunması ÜK etyopatogenezinde azalmış PON1 seviyelerine bağlı gelişen oksidatif hasarın etkili olabileceği fikrini desteklemektedir. Benzer şekilde Rothem ve ark. yaptığı çalışmada kolon ve ileumdan alınan biyopsi örneklerinde PON1 eksikliği gözlenmiş ve bu parametrelerin hastalığın patogenezinde rol alabileceği söylenmiştir (25).

Baskol ve ark.'nın yaptığı çalışmada PON1 aktivitesi bizim çalışmamıza benzer olarak ÜK'lı grupta kontrol grubuna göre daha düşük olarak bulunmuştur (21). Baskol ve ark. çıkan bu sonuçları "Preoksidan bir çevrede inflamatuvar yanıtın bir parçası olarak artan sitokinler azalmış PON1 aktivitesine sebep olabilir." şeklinde açıklamışlardır. Ayrıca bu çalışmada serum PON1 aktivitesi ile hastalık aktivitesi arasında hiçbir korelasyon bulamamışlardır. Daha önce değişik hasta grupları ile yapılan çalışmalarda PON1 ve ARE'nin hastalık aktivitesi ile de ilişkili olabileceği gösterilmesine rağmen bizim çalışmamız ve yukarıda bahsedilen çalışmada tam tersi sonuçlar bulunmuştur. Bunun olası nedenlerinden biri ise hastaların aktif ve remisyon döneminde kullandığı immünsupresif ilaçlara bağı sonuçların yanlış değerlendirilmesi olabilir. Diğer bir sebebi ise PON1'in gerçekten C-reaktif protein (CRP) gibi sık kullanılan parametrelere göre hastalık aktivitesini değerlendirmek için yetersiz kalması olabilir. Nitekim Boehm ve ark. yaptıkları çalışmada Crohn hastalı̆̆ı ve ÜK varlığında azalan PON1 enzim aktivitesini CRP yüksekliği ile karşılaştırmış ve zayıf bir belirteç olarak saptamışlardır. PON1 enzim aktivitelerinin düşük sensitivite ve spesifiteye sahip olması nedeniyle hastalık aktivitesini değerlendirme gücü

\section{KAYNAKLAR}

1. Çavuşoğlu H, İliçin $G$, Ünal S, Biberoğlu K, Süleymanlar G. İnflamatuar barsak hastalığı. İç Hastalıkları. 2. baskı. Ankara: Güneş Kitabevi, 2003:1577-90.

2. Tezel A. Etiopathogenesis of ulcerative colitis. Turkiye Klinikleri J Gastroenterohepatol-Special Topics 2009;2:7-12.

3. Fiocchi $C$. Future of IBD pathogenesis: How much work is left to do? Inflamm Bowel Dis 2008;14(Suppl 2):S145-7.

4. Friedman S, Blumberg RS. Inflammatory bowel disease. In; Braunwald E, Fauci AS, Kasper DL, et al. (eds). Harrison's Principles of Internal Medicine. 16th ed. New York; McGraw-Hill. 2005;1776-89.

5. Draganov DI, Teiber JF, Speelman A, et al. Human paraoxonases (PON1, PON2, and PON3) are lactonases with overlapping and distinct substrate specificities. J Lipid Res 2005;46:1239-47.

6. Mackness B, Durrington PN, Mackness MI. Human serum paraoxonase. Gen Pharmacol 1998;31:329-36.

7. Costa LG, Vitalone A, Cole TB, Furlong CE. Modulation of paraoxonase (PON1) activity. Biochem Pharmacol 2005;69:541-50. klinik uygulamalar için yeterince güvenilir bulunamamıştır (26).

ÜK'li hastalarda serum PON1 ve ARE aktivitesindeki azalmanın mekanizması tam olarak bilinmemektedir. ÜK'da inflame mukozadaki azalmış antioksidan seviyeleri sonucunda, artan serbest oksijen radikalleri ile oluşan oksidatif stres doku hasarına neden olur. Serum PON1 ekspresyonunun oksidatif stresle azaldığı ve yapılan çalışmalarda oksidatif stres durumlarında PON1'in inaktive olduğu gösterilmiştir $(27,28)$. Ayrıca inflamatuvar bir hastalık olan ÜK'da inflamatuvar yanıtın bir parçası olarak TNF- $\alpha$ ve interlökin (IL)-1'in arttığı (29-31) ve bunun sonucunda da IL-1 ve TNF- $\alpha$ 'nın serum PON1 aktivitesini azalttığı belirtilmiştir (32). PON1 dominant olarak karaciğerde üretilir ve IL-1, TNF- $\alpha$ gibi sitokinler karaciğer hücrelerine direkt etki ederek PON1 mRNA'nın azalmasına neden olurlar. Bu tezi destekler nitelikte Van Lenden ve arkadaşlarının yaptığı bir çalışmada akut faz cevabı sırasında TNF- $\alpha$ ve IL-1 gibi salınan mediyatörlerin serum PON aktivitesini azalttığı bulunmuş ve PON negatif akut faz proteini olarak kabul edilmiştir (33).

Çalışmamızın en önemli kısıtılığı hasta sayısının az olmasıdır. Ancak literatürde PON1 ve ARE ile yapılmış çalışmalarda bizim hasta sayımıza benzer hasta örneklemleri kullanılmıştır ve hasta sayımız istatistiksel değerlendirme için yeterlidir.

Sonuç olarak bu çalışmada ÜK'lı hastalarda PON1 ve ARE aktivitelerinin kontrol grubuna göre istatiksel olarak anlamlı şekilde azaldığı ancak bu parametrelerin hastalık aktivitesi ile ilişkili olmadığı tespit edilmiştir. Bu sonuçlara göre PON1 ve ARE'nin hastalığın etyopatogenezinde rol alabileceği düşünülmüştür.

8. Mackness B, McElduff P, Mackness MI. The paraoxonase-2-310 polymorphism is associated with the presence of microvascular complications in diabetes mellitus. J Intern Med 2005;258:363-8.

9. Baum L, Ng HK, Woo KS, et al. Paraoxonase 1 gene Q192R polymorphism affects stroke and myocardial infarction risk. Clin Biochem 2006;39:191-5.

10. Suchocka Z, Swatowska J, Pachecka J, Suchocki P. RP-HPLC determination of paraoxonase activity in human blood serum. J Pharm Biomed Anal 200611;42:113-9.

11. Gokdemir MT, Karakilcik AZ, Gokdemir GS. Prognostic importance of paraoxonase, arylesterase and mean platelet volume efficiency in acute ischaemic stroke. J Pak Med Assoc 2017;67:1679-83.

12. Utanğaç MM, Yeni E, Savaş $M$, et al. Paraoxonase and arylesterase activity in bladder cancer. Turk J Urol 2017;43:147-51.

13. Kul A, Uzkeser H, Ozturk N. Paraoxonase and arylesterase levels in Behcet's Disease and their relations with the disease activity. Biochem Genet 2017;55:335-44. 
14. Trulove SC, Witts LJ. Cortisone in ulcerative colitis; preliminary report on a therapeutic trial. Br Med J 1954;2:375-8.

15. Isik A, Koca SS, Ustundag B, et al. Paraoxonase and arylesterase levels in rheumatoid arthritis. Clin Rheumatol 2007;26:342-8.

16. Kafadar AM, Ergen A, Zeybek U, et al. Paraoxonase 192 gene polymorphism and serum para־oxonase activity in high grade gliomas and menegiomas. Cell Biochem Funct 2006;24:455-60.

17. Yıldıım A, Aslan Ş, Ocak T, Yıldıım S, Kara F, Şahin YN. Serum paraoxonase/arylesterase activities and malondialdehyde levels in trauma patients. Eurasian J Med 2007;39:85-8.

18. Akçay MN, Yilmaz I, Polat MF, Akçay G. Serum paraox`onase levels in gastric cancer. Hepatogastroenterology 2003;50(Supp 2): cclxxiii-cclxxv.

19. Akçay MN, Polat MF, Yilmaz I, Akçay G. Serum paraoxonase levels in pancreatic cancer. Hepatogastroenterology 2003;50(Suppl 2): ccxxv-ccxxvii.

20. Elkiran ET, Mar N, Aygen B, et al. Serum paraoxonase and arylesterase activities in patients with lung cancer in a Turkish population. BMC Cancer 2007; 15:48.

21. Başkol G, Başkol M, Yurci A, et al. Serum paraoxonase 1 activity and malondialdehyde levels in patients with ulcerative colitis. Cell Biochem Funct 2006;24:283-6.

22. D'Inca R, Cardin R, Benazzato $L$, et al. Oxidative DNA damage in the mucosa of ulcerative colitis increases with disease duration and dysplasia. Inflamm Bowel Dis 2004;10:23-7.

23. Sturniolo GC, Mestriner C, Lecis PE, et al. Altered plasma and mucosal concentrations of trace elements and antioxidants in active ulcerative colitis. Scand J Gastroenterol 1998;33:644-9.

24. Ferretti G, Bacchetti T, Moroni C, et al. Copper-induced oxidative damageon astrocytes: protective effect exerted by human high density lipoproteins. Biochimica Biophysica Acta 2003;1635:48-54.
25. Rothem L, Hartman C, Dahan A, et al. Paraoxonases are associated with intestinal inflammatory diseases and intracellularly localized to the endoplasmic reticulum. Free Radic Biol Med 2007;43:730-9.

26. Boehm D, Krzystek-Korpacka M, Neubauer K, et al. Paraoxonase-1status in Crohn's disease and ulcerative colitis. Inflamm Bowel Dis 2009;15:93-9.

27. Aviram M, Rosenblat M. Paraoxonases 1, 2, and 3, oxidative stress, and macrophage foam cell formation during atherosclerosis development. Free Radic Biol Med 2004;37:1304-16.

28. Mackness $B$, Durrington $P$, McElduff $P$, et al. Low paraoxonase activity predicts coronaryevents in the Caerphilly Prospective Study. Circulation 2003;107:2775-9.

29. Nakamura M, Saito $H$, Kasanuki J, et al. Cytokine production in patients with inflammatory bowel disease. Gut 1992;33:933-7.

30. Olson AD, Ayass M, Chensue S. Tumor necrosis factor and IL-1 beta expression in pediatric patients with inflammatory bowel disease. J Pediatr Gastroenterol Nutr 1993;16:241-6

31. Funakoshi K, Sugimura K, Sasakawa T, et al. Study of cytokines in ulcerative colitis. J Gastroenterol 1995;30(Suppl 8):61-3.

32. Kumon $Y$, Nakauchi $Y$, Suehiro $T$, et al. Proinflammatory cytokines but not acute phase serum amyloid A or C-reactive protein, downregulate paraoxonase 1 (PON1) expression by Hep G2 cells. Amyloid 2002;9:160-4.

33. Van Lenten BJ, Hama SY, de Beer FC, et al. Anti-inflammatory HDL becomes pro-inflammatory during the acute phase response. Loss of protective effect of $\mathrm{HDL}$ against LDL oxidation in aortic wall cell cocultures. J Clin Invest 1995;96:2758-67. 